\title{
BIO-CHAR AND BIO-OIL MIXTURE DERIVED FROM THE PYROLYSIS OF MESOCARP FIBRE FOR BRIQUETTES PRODUCTION
}

\author{
SAFANA, A $A^{*} ;$ ABDULLAH, $\mathrm{N}^{\star *}$ and SULAIMAN, $\mathrm{F}^{\star *}$
}

\begin{abstract}
A huge amount of mesocarp fibre (MF) is generated as wastes in Malaysia. These wastes will continue to pose disposal problems in Malaysia, unless effectively deployed. This research aims to produce charcoal briquettes from the pyrolysis products of such wastes (bio-char and bio-oil). The MF was pyrolysed at a temperature of $400^{\circ} \mathrm{C}$, a heating rate of $10^{\circ} \mathrm{C} \mathrm{min}^{-1}$ for $1 \mathrm{hr}$. Sago starch was added to improve the bio-oil viscosity. Bio-char and bio-oil binder were mixed respectively in the ratio of 70:30 for the charcoal briquettes production. Bio-oil viscosity was improved to 49.6 cP from 1.9 cP. Consequently, higher heating value (HHV), $p H$ value and density of bio-oil were increased to $21.23 \mathrm{MJ} \mathrm{kg-1}$ from $17.06 \mathrm{MJ} \mathrm{kg}^{-1}, 4.76$ from 3.14 and $1529 \mathrm{~kg} \mathrm{~m}^{-3}$ from $1337 \mathrm{~kg} \mathrm{~m}^{-3}$, respectively. The physio-chemical properties and the durability of the briquettes were analysed and compared to briquettes obtained with sago starch binder. The results have revealed that briquettes made with bio-oil binder had high HHV of $29.1 \mathrm{MJ} \mathrm{kg-1}^{-1}$, density, and water resistance. The briquettes made with sago binder were more durable. This study could boost the application of pyrolysis products, especially bio-oil which has some disadvantages as fuel. It can reduce the dependence on fossil fuels such as coal in some applications.
\end{abstract}

Keywords: charcoal briquette, bio-oil binder, fuel quality.

Date received: 23 February 2017; Sent for revision: 12 May 2017; Received in final form: 30 October 2017; Accepted: 10 January 2018.

\section{INTRODUCTION}

The biomass wastes generated from palm oil mills consist of mesocarp fibres (MF), kernel shells and empty fruit bunches (EFB). The palm trunks and palm fronds are generated at oil palm plantations (Uemura et al., 2011). These oil palm residues contain various chemical compositions and have a high heating value of about 18-19 $\mathrm{MJ} \mathrm{kg}^{-1}$. They can be better fuels in the form of pellets and briquettes (Lam

* Department of Physics,

Federal University Dutse,

P.M.B 7156 Ibrahim Aliyu Way Bypass,

Dutse, Nigeria.

** School of Physics,

Universiti Sains Malaysia,

11800 Minden, Pulau Pinang, Malaysia.

E-mail: basalihe2@gmail.com et al., 2015). For instance, in producing $1 \mathrm{~kg}$ of palm oil about $4 \mathrm{~kg}$ of dry oil palm biomass are generated (Sulaiman et al., 2010). They could be transformed into other forms of useful energy resources. Fibre and shells are utilised as fuel in palm oil mill to power the processing plants (Sulaiman et al., 2011).

Briquetting is mainly identified as a technology for materials compacting. The technology involves compressing biomass materials into smaller and denser products (briquettes). The briquette quality can be determined by such physical factors like density, moisture content, and compressive strength (Kask et al., 2010). The binder, moisture content, particle size and compressing forces (pressure) are among the factors that affect the quality of briquettes in terms of durability and resistivity during transportation (Kaliyan and Vance, 2009). The densification of biomass enhances bulk density, 
strength and consistency of briquettes or pellets. Particle size reduction is vital and has a significant role in the overall densification system (Morey, 2009).

The pyrolysis conversion process is one of the prominent methods through which biomass are converted into three major by-products namely solid char, bio-oil and gases (Sukiran, 2011; Abnisa et al., 2013a). Bio-char is produced during the pyrolysis of biomass materials. The biomass is heated in an oxygen-free environment at a temperature range of $300^{\circ} \mathrm{C}-1000^{\circ} \mathrm{C}$. Bio-char is described as charred organic matter, which can be used to improve soil quality through sequestering carbon in the soils, thus reducing the greenhouse gas (GHG) emission. It is a steady carbon compound that can stay on the ground for over hundreds of years (Sulaiman et al., 2011; Abdullah and Sulaiman, 2013). Bio-oil is described as a dark brown liquid with a heating value almost similar to oxygenated fuels like methanol and ethanol (Aziz et al., 2013). It has been considered as an alternative to fossil fuels such as petroleum and diesel to produce power (Aziz et al., 2013; Xiu and Shahbazi, 2012). Bio-oil is environmentalfriendly, unlike fossil fuels, because it is $\mathrm{CO}_{2} / \mathrm{GHG}-$ free. However, some factors affect the application of bio-oil as a potential substitute for petroleum fuels and chemical; they include high water and ash contents, instability, high corrosiveness, low heating value, and high viscosity. Therefore, improving the bio-oil is recommended to increase its quality to be utilised for many purposes (Xiu and Shahbazi, 2012). Although there are many studies on biomass briquetting, limited researches have been conducted on making briquette from such pyrolysed biomass products. For this reason, this study is intended to produce briquettes from the mixture of bio-char and bio-oil.

\section{MATERIALS AND METHODS}

\section{Material Collection and Preparation}

The oil palm biomass studied, i.e., MF was obtained from a palm oil mill located in Nibong Tebal, Pulau Pinang, Malaysia. This biomass material was a by-product of a different milling process such as pressing and nut cracking during the crude palm oil production. The moisture content of the biomass as received was $13.1 \mathrm{wt} . \%$. The biomass material was dried for $24 \mathrm{hr}$ at $105^{\circ} \mathrm{C}$ to further remove the moisture. Sago starch used was bought from Mydin shopping mall located at Bukit Jambul, Pulau Pinang, Malaysia.

\section{Pyrolysis Experiment}

The pyrolysis experiment was conducted three times separately using a stainless steel reactor of
$150 \mathrm{~mm}$ length and $70 \mathrm{~mm}$ internal diameter. The reactor was fed with about $180 \mathrm{~g}$ of the raw material and placed inside the electric furnace. The reactor was heated to $400^{\circ} \mathrm{C}$ using an electric furnace at a constant heating rate of $10^{\circ} \mathrm{C} \mathrm{min}{ }^{-1}$ for $1 \mathrm{hr}$. During the experiment, 2 litre min $^{-1}$ of nitrogen gas was circulated throughout the pyrolyser. The reactor temperature was monitored by a K-type thermocouple inserted inside the reactor. The condensable and noncondensable gasses were passed through a cooling system which was regulated at $5^{\circ} \mathrm{C}$. The bio-oil produced was condensed and collected in the flasks numbered 1 and 2, whereby the non-condensable gasses exit the system through the gas outlet as shown in Figure 1. Before and after each run, the reactor weight was measured, and the quantity of solid product (bio-char) left was calculated from the difference. The bio-oil yield was calculated by subtracting initial from final weight of flasks, condensers, L-tube, long tube and pipes, while noncondensable gas was derived from the difference of bio-char and bio-oil from $100 \%$.

\section{Bio-oil Viscosity Enhancement}

Sago starch powder was added into the bio-oil to enhance the bio-oil viscosity. Physiochemical properties of the bio-oils such as density, viscosity, water content, acidity and calorific value were determined. The boiling point of bio-oil was determined by heating the bio-oil inside a beaker with a bunsen burner, and a K-type thermocouple was placed inside the beaker to monitor the temperature. Three values of the temperature were recorded, and the average was used as the boiling point.

The ratio of 90:10 for bio-oil and sago starch powder was prepared. Bio-oil (90 wt.\%) was poured into a covered beaker $(150 \mathrm{ml})$ and then placed into an oven and heated to $105^{\circ} \mathrm{C}$ for $3 \mathrm{hr}$. The weight of the beaker was measured before and after. And, 10 wt.\% of sago starch powder was placed into another beaker. After exactly $3 \mathrm{hr}$, bio-oil was taken out from the oven, and sago starch was added immediately into the heated bio-oil which was stirred. The mixture (bio-oil binder) was heated again for $2 \mathrm{hr}$ at a temperature of $130^{\circ} \mathrm{C}$. It was taken out from the oven, shaken vigorously and allowed to cool to room temperature. Sago starch was also prepared as a binder without the bio-oil (sago binder).

\section{Briquettes Production}

The cylindrical briquette mold used was made from hardened steel with an inner diameter of 19.4 $\mathrm{mm}$ and a height of $50.2 \mathrm{~mm}$. Other briquette parts are press piston $55.0 \mathrm{~mm}$ and stop piston $10.0 \mathrm{~mm}$. The manual hydraulic pressing machine (briquette maker) used has a maximum pressuring capacity 


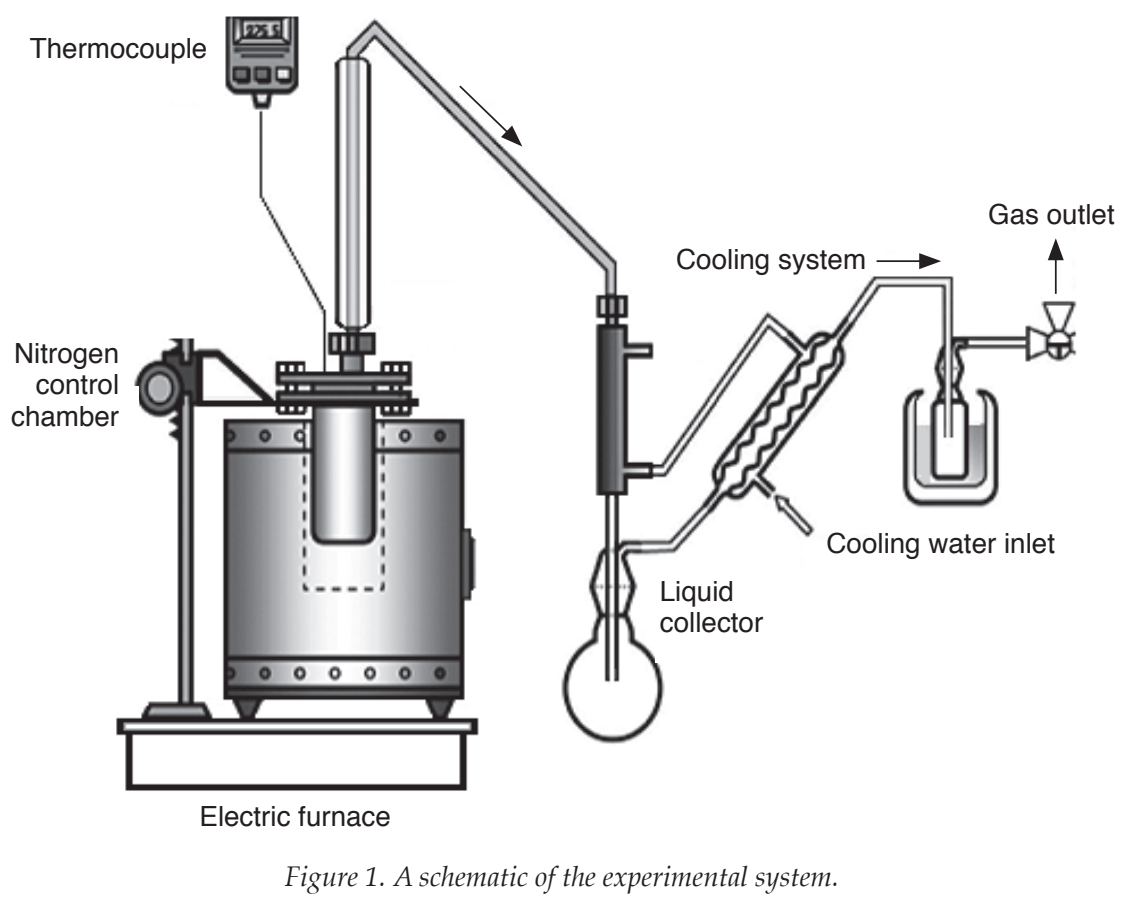

of $1000 \mathrm{~kg} \mathrm{~cm}^{-2}$. For each briquette made, about 10 - $15 \mathrm{~g}$ of the mixture was placed into a mold and compressed at $150 \mathrm{~kg} \mathrm{~cm}^{-2}$ for $5 \mathrm{~min}$. This procedure was replicated for all the briquettes produced. Biochar was grinded into the size of fine particles. The ratio of bio-char and bio-oil binder was 70:30 weight percentages. The mixture was allowed to dry for 30 min at room temperature before feeding into the mold and pressed. Besides, other sets of briquettes were produced using sago starch as a binder and hot water in the ratio of 20:80. The weight of briquettes produced was recorded instantly and placed under ambient conditions for about 10 days to dry and stabilise.

\section{Physio-chemical Characterisation}

Thermogravimetric analysis (TGA) was performed on the biomass. It was performed using model Perkin Elmer STA 6000 thermogravimetric analyser. It was conducted to examine the thermal performance of the sample by observing the weight alteration that happened as the sample was heated with regards to hemicellulose, cellulose, lignin and their thermal degradation behavior. The analysis was carried out in the presence of nitrogen $\left(\mathrm{N}_{2}\right)$ gas flow and under $5^{\circ} \mathrm{C} \mathrm{min}^{-1}$ heating rate. The sample size of 250-355 $\mu \mathrm{m}$ was heated from ambient temperature to about $900^{\circ} \mathrm{C}$. The lignocellulosic compositions of the MF were measured according to the procedure prescribed by (Li et al., 2004).

Proximate analysis was carried out according to ASTM E871 for moisture content, ASTM E872 for volatile matter and ASTM E1755 - 01 for ash content. The fixed carbon was determined by the difference.
Elemental analysis was conducted to analyse the percentage of carbon $(\mathrm{C})$, hydrogen $(\mathrm{H})$, nitrogen $(\mathrm{N})$, sulphur (S) and oxygen $(\mathrm{O})$. The elemental analysis was performed using Perkin Elmer 2400 analyser, 2 - $2.8 \mathrm{mg}$ of sample was used to measure the percentage weight of each element present. The higher heating value (HHV) was determined using a bomb calorimeter system IKA C 200, oxygen station C248 with an empty water hose. For each test run, about $0.5-0.8 \mathrm{~g}$ of the sample was measured and placed in the crucible joined to the thread from the ignition wire, closed and oxygen gas was pumped in. However, the lower heating value (LHV) was calculated using HHV and hydrogen content measured as shown in Equation (1) (Adisak, 2006). LHV is more important than HHV, attributable to the fact that LHV does not have any input from the latent heat of the vapour (Uemura et al., 2011). The results of the analyses were presented in Table 1.

$\operatorname{LHV}_{\text {dry }}\left(\mathrm{MJ} \mathrm{kg}^{-1}\right)=\mathrm{HHV}_{\mathrm{dry}}-2.442\left(\frac{8.936 \mathrm{H}}{100}\right)$--------- Equation (1)

where $H$ is the weight percentage of hydrogen on a dry basis.

The water content of the bio-oils was determined by using Karl Fischer Titration, (870 KF Titrino Plus). The bio-oils were initially titrated with standard Karl Fischer reagent to an electrometric endpoint. Approximately $1 \mathrm{~g}$ sample was weighed out exactly into a dry Erlenmeyer flask fitted with a septum stopper. It was treated with about 20-25 g dry solvent (mixture), the container was then sealed and the contents mixed. Part of the mixture is drawn 
TABLE 1. THE PHYSIO-CHEMICAL PROPERTIES OF MESOCARP FIBRE AND SAGO

\begin{tabular}{|c|c|c|c|c|}
\hline Material (wt $\%)$ & Sago & Fibre & Literature & Reference \\
\hline \multicolumn{5}{|c|}{ Lignocellulosic Components } \\
\hline Cellulose & ---- & 32.6 & 33.9 & Kong et al. (2014) \\
\hline Hemicellulose & ----- & 29.2 & 26.1 & Abnisa et al. (2013) \\
\hline Lignin & ---- & 27.9 & 27.7 & Mahmood et al. (2015) \\
\hline Extractives & ----- & 10.3 & 6.7 & Kong et al. (2014) \\
\hline Ash & ----- & ---- & 3.5 & Kong et al. (2014) \\
\hline \multicolumn{5}{|l|}{ Elements analysis $^{\mathrm{a}}$} \\
\hline Carbon & 44.75 & 46.37 & 45.03 & Yuliansyah (2012) \\
\hline Hydrogen & 6.50 & 5.52 & 6.15 & Yuliansyah (2012) \\
\hline Nitrogen & 0.25 & 0.59 & 0.94 & Yuliansyah (2012) \\
\hline Sulphur & ---- & 0.12 & --- & Abdullah (2008) \\
\hline Oxygen $^{b}$ & 48.50 & 47.47 & 47.89 & Yuliansyah (2012) \\
\hline \multicolumn{5}{|l|}{ Proximates analysis ${ }^{\mathrm{a}}$} \\
\hline Moisture & 3.29 & 6.2 & 8.6 & Uemura et al. (2011) \\
\hline Volatile & 79.47 & 77.15 & 78 & Mahmood et al. (2015) \\
\hline Ash & 2.21 & 7.02 & 5.8 & Uemura et al. (2011) \\
\hline Fixed carbon ${ }^{b}$ & 15.03 & 15.83 & 7.6 & Uemura et al. (2011) \\
\hline \multicolumn{5}{|l|}{ Calorific value $\left(\mathrm{MJ} \mathrm{kg}^{-1}\right)$} \\
\hline Higher heating value & 14.65 & 19.06 & 19.06 & Uemura et al. (2011) \\
\hline Lower heating value & 13.23 & 17.86 & 18.31 & \\
\hline M formula & $\mathrm{CH}_{1.73} \mathrm{O}_{0.81}$ & $\mathrm{CH}_{1.42} \mathrm{~N}_{0.01} \mathrm{O}_{0.77}$ & & \\
\hline
\end{tabular}

Note: ${ }^{a}$ Weight percentage dry basis $(\mathrm{wt} \%)$ and ${ }^{\mathrm{b}}$ by difference. M. formula - molecular formula.

off into a sterile syringe, and the syringe and its contents are tared. Some of the mixtures are injected into the titration vessel and titrated. The amount of sample injected is determined by back-weighing the syringe. A Fisher Scientific Accumet AB15/15+ pH meter made from Singapore was used to determine the $\mathrm{pH}$ value of the bio-oils. The $\mathrm{pH}$ meter contains electrode and temperature sensors. The bio-oil sample was placed into a beaker; electrode and temperature probe was immersed into the sample solution. The solution is stirred moderately until the meter sensors display a stable reading icon on the screen. This measurement was conducted at room temperature.

The viscosity of bio-oils was determined using a portable Rion viscometer (VT - 03/04). The viscometer used can measure a thickness range of between 15 - $150 \mathrm{cP}$ and have parts such as cup A and $\mathrm{B}$, bracket for attachment and cylindrical rotor number 1 - 5. About $120 \mathrm{ml}$ of bio-oil was measured at $25^{\circ} \mathrm{C}$ and placed in the cup to its edge. The cup was attached to the bracket and connected to the rotor, and the power was on and run for about $40 \mathrm{~s}$. The viscosity values were directly taken on the meter by rotating a rotor in the sample fluids which causes viscous resistance. The density is a temperaturedependent measuring unit. The densities of bio-oils were measured at a temperature between $25^{\circ} \mathrm{C}$ $30^{\circ} \mathrm{C}$ using Portable Density Meter, DMA 35 Portable Density/Specific Gravity/Concentration Meter. DMA 35 measures the density of liquids in $\mathrm{g} \mathrm{cm}^{-3}$ or $\mathrm{kg} \mathrm{m}^{-3}$ according to the oscillating $\mathrm{u}$-tube principle. A temperature sensor measures the temperature of the sample right at the measuring cell. Samples are filled into the measuring cell using the built-in pipette-style pump or a syringe. The readings were taken directly from the screen.

The determination of the functional group(s) in the biomass, bio-char, and bio-oils was conducted using PerkinElmer Spectrum 100 Series FTIR spectrometer. The samples were scanned at wave numbers ranging from $400 \mathrm{~cm}^{-1}-4000 \mathrm{~cm}^{-1}$ at a resolution of $4 \mathrm{~cm}^{-1}$, the infrared (IR) spectra of the samples were studied and analysed. A few solid samples were organised collectively with a small amount of spectroscopy $(\mathrm{KBr})$ powder and compacted into a solid disk. And, for the liquids samples, a little amount of the liquid was climbed on a potassium bromide $(\mathrm{KBr})$ disc that had been earlier scanned as a background. In this work, the morphology of biomass and biochar was characterised using a scanning electron microscopy (SEM). It was conducted using EVO/MA10 model SEM which was controlled at a $20 \mathrm{kV}$ accelerated voltage and magnification of $500 \mathrm{mag}$. Before the SEM, the sample was sieved to a uniform size of about $150 \mu \mathrm{m}$ and dried in an oven for $24 \mathrm{hr}$ at $105^{\circ} \mathrm{C}$. There was no coating before SEM analysis.

The quality of briquettes is affected by moisture and water when exposed in the course of transportation or application. Therefore, the water absorbed by the briquettes was investigated in this work. Briquettes produced were immersed in a beaker filled with cold tap water for $5 \mathrm{~min}$. The weights of the briquettes and glass were measured before and after soaking. The difference determines the water absorbed. This procedure was adopted with some modification from Kaliyan and Vance 
(2009). The compressive strength test was conducted using Testometric M350 - 10 kN, 2MSB Tensile Test with a capacity of $1000 \mathrm{~N}$ loads and height of 500 $\mathrm{mm}$. The briquette assessed was positioned straight in the compression chamber, and an increasing load was applied at a steady rate of $50 \mathrm{~mm} \mathrm{~min}^{-1}$ until the briquette failed by crashing. Subsequently, a force which corresponds to the crash point was recorded. The highest load to cause a crash of briquette was read on the screen of a computer connected to the Testometric machine. Finally, the compressive strength was calculated by dividing load at fracture point by cross-sectional area of the plane of fracture (Suparin, 2007).

$\begin{aligned} & \text { Compressive } \\ & \text { strength }\left(\mathrm{N} \mathrm{mm}^{-2}\right)\end{aligned}=\frac{\begin{array}{l}\text { Load at briquette } \\ \text { failure }(\mathrm{N})\end{array}}{\begin{array}{l}\text { Cross-sectional area } \\ \text { of briquette }\left(\mathrm{mm}^{-2}\right)\end{array}}$------- Equation (2)

The hardness of the briquettes was found in agreement with the Shattered index (Tembe et al., 2014). The weights of the briquettes were weighed before and after the shatter index test. Each briquette sample was permitted to drop from a standard height of $2 \mathrm{~m}$ onto a metal base for 12 times. The briquette portion which remained was measured. The shatter index was calculated as the ratio of the weight of briquette which remained after dropping to the initial weight of briquettes before dropping as given by the following equation.

$$
\text { Shatter index }=\frac{\begin{array}{c}
\text { Weight of briquette } \\
\text { remained after dropping }
\end{array}}{\begin{array}{c}
\text { Weight of briquette } \\
\text { before dropping }
\end{array}} \text {------- Equation (3) }
$$

The density of briquettes was measured in this work. The weights of briquettes were measured using a digital weighing balance, and to calculate the volume of briquettes the average diameters and heights of the briquettes were taken at three positions with Vanier caliper. This procedure was adopted with modification from Tembe et al. (2014). The density was then calculated (Equation 4).

$$
\mathrm{Q}\left(\mathrm{g} \mathrm{cm}^{-3}\right)=\mathrm{m} / \mathrm{v} \text {------------ Equation (4) }
$$

where $m$ is the briquette weight, and $V$ is the briquette volume.

\section{RESULTS AND DISCUSSION}

\section{Characterisation of Raw Materials}

Jahirul et al. (2012) reported that the quantities of volatile matter, fixed carbon, ash content, and moisture influenced pyrolysis products. Biomass with a high volatile matter generates large amounts of bio-oil and syngas, whereas fixed carbon favours the biochar yield. The moisture content in the biomass influences the heat transfer system with primary outcomes on product distribution. A higher moisture content increases the liquid product yield and reduces the yield of solid and gas product; this could be associated with the tremendous amount of condensate water generated from the moisture in the liquid phase. The proximate, elemental, lignocellulose constituents, LHV and HHV of raw biomass and sago are presented in Table 1. The results were also displayed along with values from the literature. The elemental compositions of sago are 44.7 wt.\% carbon, 48.50 wt.\% oxygen, 6.50 wt.\% hydrogen and 0.25 wt. $\%$ nitrogen. The molecular formula of sago (CH1.7300.81) was calculated from the elemental composition. The HHV and LHV of sago were $14.65 \mathrm{MJ} \mathrm{kg}^{-1}$ and $13.23 \mathrm{MJ} \mathrm{kg}^{-1}$. Comparatively, another binder like cassava stalk has $\mathrm{HHV}$ of $17.58 \mathrm{MJ} \mathrm{kg}^{-1}$ and carbon content of 51.12 wt.\% higher than that of sago (Adisak, 2006). The volatiles, fixed carbon, ash and moisture contents of sago are 79.47, 15.03, 2.21 and 3.29 wt. \%, respectively.

The main lignocellulosic components of biomass are cellulose, hemicelluloses, and lignin. The percentage composition of these constituents plays a vital function in the pyrolysis products (Abnisa et al., 2013b). Therefore, the contents matter a lot in choosing biomass feedstocks for pyrolysis. The contents of cellulose, hemicelluloses, and lignin for MF from Table 1 are 32.6, 29.2, and 27.9 wt.\%. Similar results were reported in work of Abnisa et al. (2013b), Kong et al. (2014) and Mahmood et al. (2015).

The TGA and difference thermogravimetric (DTG) curve profiles for MF are presented in Figure 2. The prominent biomass lignocellulosic constituents of the fibre are hemicellulose, cellulose, lignin and extractive (Table 1). However, the order of decomposition of the biomass depends on the constituents. From the TGA and DTG curves, it can be noticed that the high rate of devolatilisation of fibre sample is between $200^{\circ} \mathrm{C}$ and $300^{\circ} \mathrm{C}$. It is believed that within this zone, the decomposition of extractives and hemicellulose reached its zenith. The decomposition of cellulose and lignin in this zone is also notably observed. The highest weight loss of $29.46 \%$ was recorded between $200^{\circ} \mathrm{C}-300^{\circ} \mathrm{C}$. This could be due to a high degree of hemicellulose and cellulose degradation. However, there is no identical peak observed for lignin. Therefore, the active pyrolysis zone for fibre could be between $200^{\circ} \mathrm{C}$ and $350^{\circ} \mathrm{C}$. It has been reported that the active zone for lignocellulose biomass substrates ranges between $200^{\circ} \mathrm{C}-400^{\circ} \mathrm{C}$, depending on the heating rate applied and the nature of biomass sample (Baroni et al., 2016). As evident from the DTG curves, there is an identical peak which corresponds to the active zone. The peak was at $337^{\circ} \mathrm{C}$ with the corresponding weight of $49.348 \%$. It was reported by Sulaiman and Abdullah (2011) that DTG curves for shell and 
fibre attain separate peaks for hemicellulose at around $300^{\circ} \mathrm{C}$ and cellulose above $300^{\circ} \mathrm{C}$. A similar observation was reported by Idris et al. (2012) on the same oil palm biomass sample.

The pyrolysis products of MF obtained at $400^{\circ} \mathrm{C}$ are shown in Figure 3. Bio-char yield is higher than bio-oil and gas. The high bio-char yield could be due to the lignin content present after pyrolysis, which usually decomposed at high temperature $\left(>500^{\circ} \mathrm{C}\right)$ as observed in the TGA data. However, the bio-oil and gas yields can be associated with the decomposition of cellulose and hemicellulose which happened in the active pyrolysis zone $\left(200^{\circ} \mathrm{C}-350^{\circ} \mathrm{C}\right)$. A similar finding has been reported for other biomass materials, that bio-oil is mainly obtained from the cellulose constituent, while biochar is mostly from the lignin content (Jahirul et al., 2012).

\section{Characterisation of Bio-char}

The Fourier transform infrared (FTIR) spectra of MF and bio-char samples are displayed in Figure 4. The compounds such as alcohol, phenol, alkane, ester, aromatic, carboxylic acid, ether, and alkenes were found in the samples. The $\mathrm{O}-\mathrm{H}$ stretching and bending vibrations at $3420-3450 \mathrm{~cm}^{-1}$ and $1330-1430$ $\mathrm{cm}^{-1}$ respectively, are associated with the occurrence of alcohol and phenol. The $\mathrm{C}-\mathrm{H}$ stretching and bending vibrations at 2850-2930 and $1420-1480 \mathrm{~cm}^{-1}$ respectively, are credited to the presence of alkanes compounds. The absorbance peaks at 1735-1750 $\mathrm{cm}^{-1}$ displayed the $\mathrm{C}=\mathrm{O}$ stretching vibration of the ester. The $\mathrm{C}=\mathrm{C}$ bending at $1510-1660 \mathrm{~cm}^{-1}$ and $\mathrm{C}-\mathrm{C}$ stretching vibration at $1400-1500 \mathrm{~cm}^{-1}$ represents the occurrence of aromatic compounds. The C-O

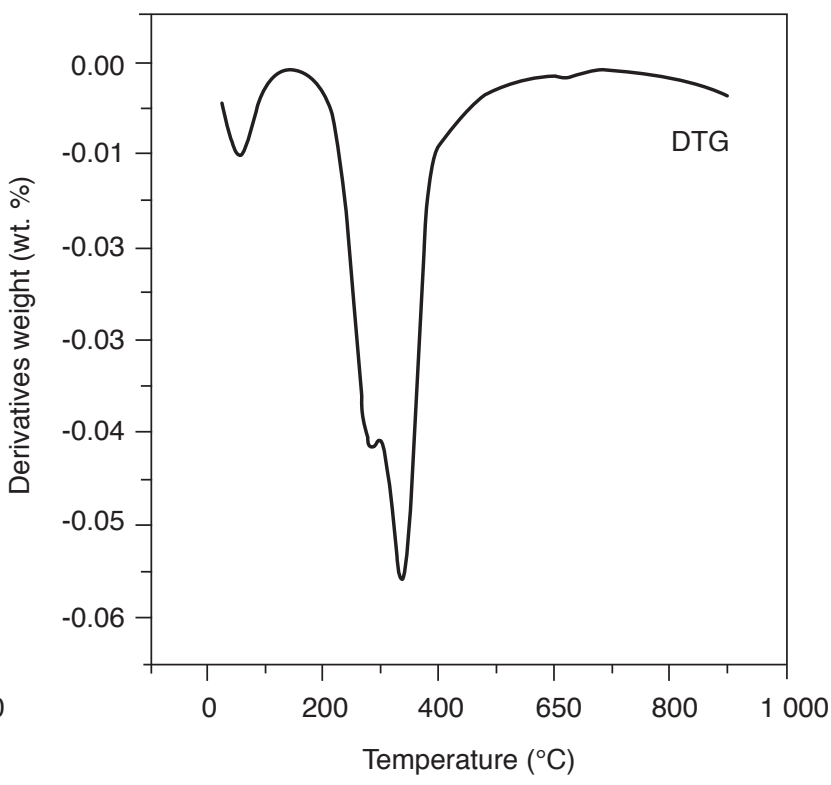

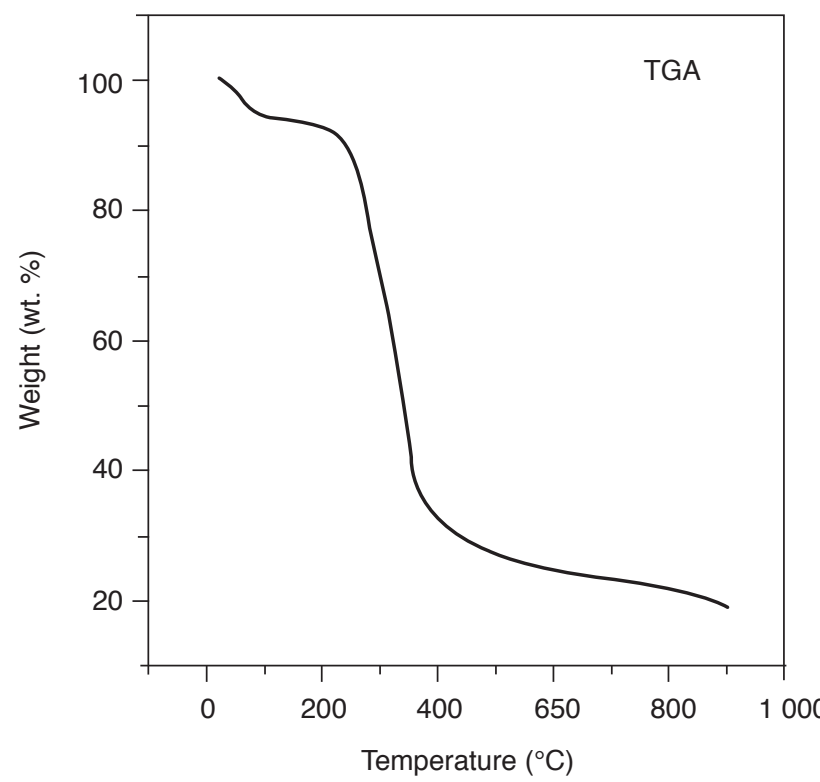

Figure 2. The thermogravimetric analysis (TGA) and difference thermogravimetric (DTG) curves for the fibre.

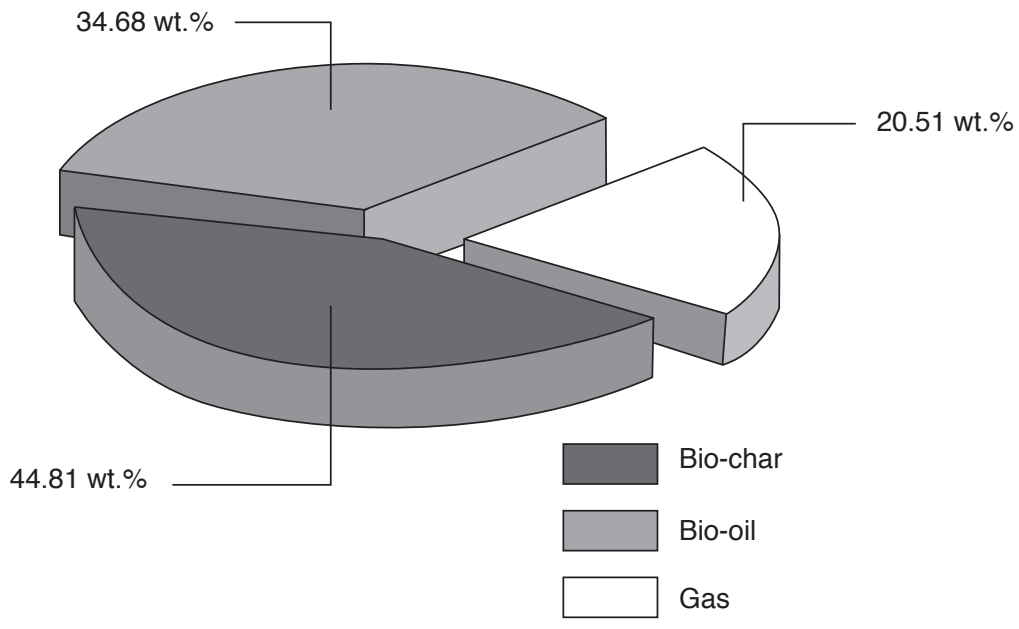

Figure 3. Yield distribution of pyrolysis products. 


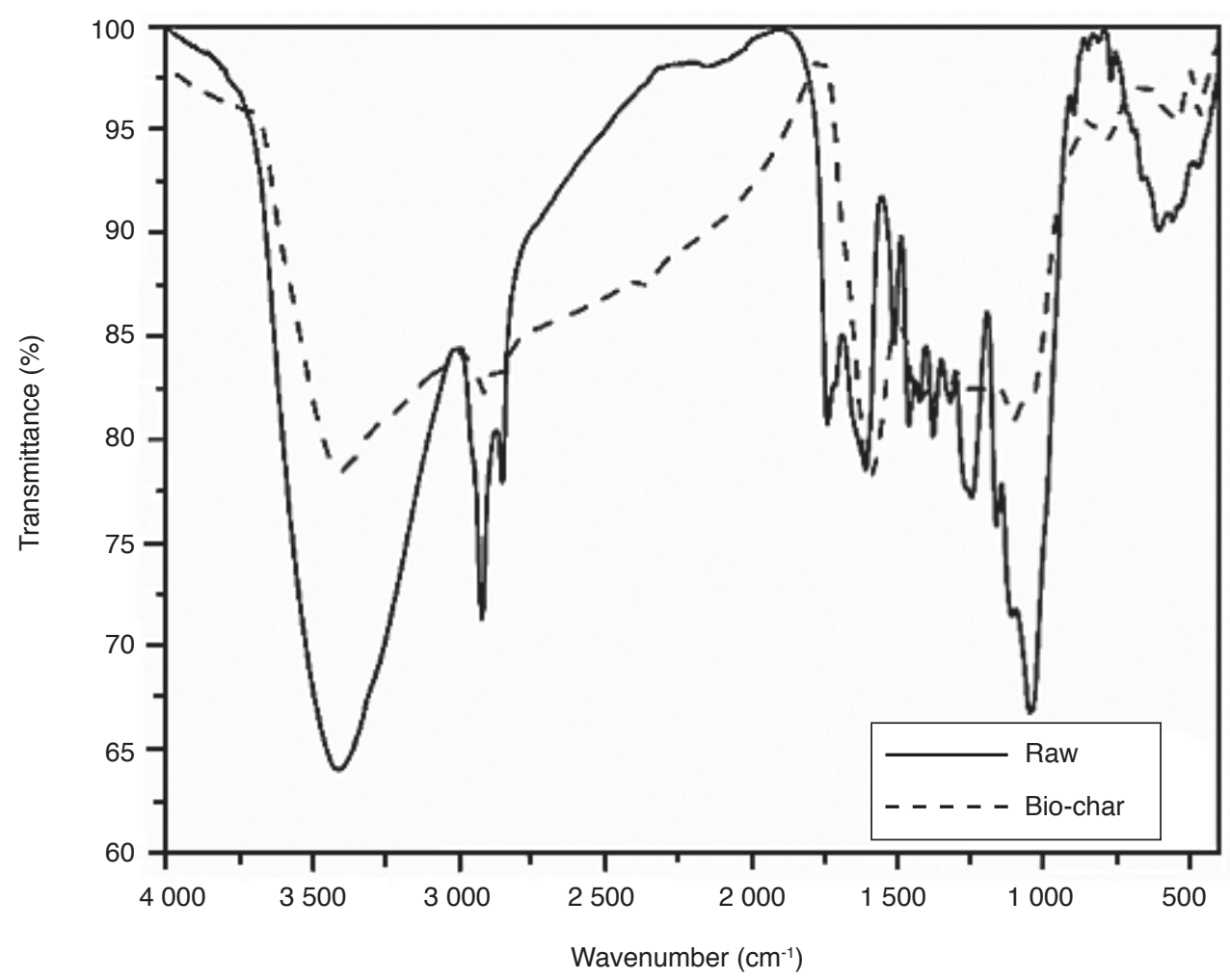

Figure 4. The Fourier transform infrared (FTIR) result of raw fibre and bio-char.

stretching vibration at $1000-1250 \mathrm{~cm}^{-1}$ represents the presence of alcohols, carboxylic acids, ester, and ether. The $\mathrm{C}-\mathrm{H}$ deformation and bending vibrations at $600-700 \mathrm{~cm}^{-1}$ and $675-900 \mathrm{~cm}^{-1}$ represents the presence of alkenes and aromatic compounds, respectively.

The same compounds were also observed in biochar but with some changes in both the shape and intensities. It can be found that the symbol of $\mathrm{OH}$ absorbance in raw sample was significantly reduced in the bio-char. This could be associated with the dehydration, water formation and discharged during the pyrolysis of biomass (Yang et al., 2006). The second bands of absorbance of alkanes (C-H stretching) at $2850-2950 \mathrm{~cm}^{-1}$ in raw was almost disappeared in the bio-char; it may be due to the breaking down of weak bonds in between $\mathrm{C}$ and $\mathrm{H}$ alkyl. The major variations between the raw and bio-char samples are the identical peaks at about $2900,1750,1000$ and $600 \mathrm{~cm}^{-1}$. The intensities of the peaks in the raw sample were drastically reduced in the bio-char sample. This could be attributed to the effect of temperature on the sample during pyrolysis. It indicates that the pyrolysis temperature controls the appearance of the functional groups. The peaks observed between $600-900 \mathrm{~cm}^{-1}$ in raw fibre reappears in bio-char. These peaks indicated the presence of aromatic and alkenes compounds in the bio-char. These findings agreed with results of Yang et al. (2006) and Abnisa et al. (2013a), respectively.
The SEM images in Figure 5, showed the structure of the raw sample and bio-char. The porous structure of bio-char can be seen in the SEM images, indicating a different shape in the pores (Moralı and Şensöz, 2015). The shape and structure of raw and bio-char were the same. However, the size of the holes differs. The average sizes of the hole for raw sample and bio-char were 4.054 and $30.075 \mu \mathrm{m}$, respectively. The larger hole in biochar may be due to the removal of volatile matter in the raw material (Table 1) which was produced and released during pyrolysis. The structure of holes and shapes generated through pyrolysis on the surface of bio-char can be observed on SEM images. However, the production of volatile matter during pyrolysis are considered responsible for the new structure, which generated other adsorption sites for ions, space for nutrients and water holding in bio-char (Moral and Şensöz, 2015). It is reported that the porous structure of bio-char can describe its influence on soil water retention and adsorption ability. Bio-char produced at low temperatures are, however, hydrophobic and this might reduce the ability to retain water. Though bio-char at low temperature is stronger than high-temperature products; it is brittle and prone to abrade into fine portions once incorporated (Sohi et al., 2009). In this work, there is not much difference in the primary physical structure of bio-char and raw material. Similar findings have been stated by Garcia-Jaramillo et al. (2015). 

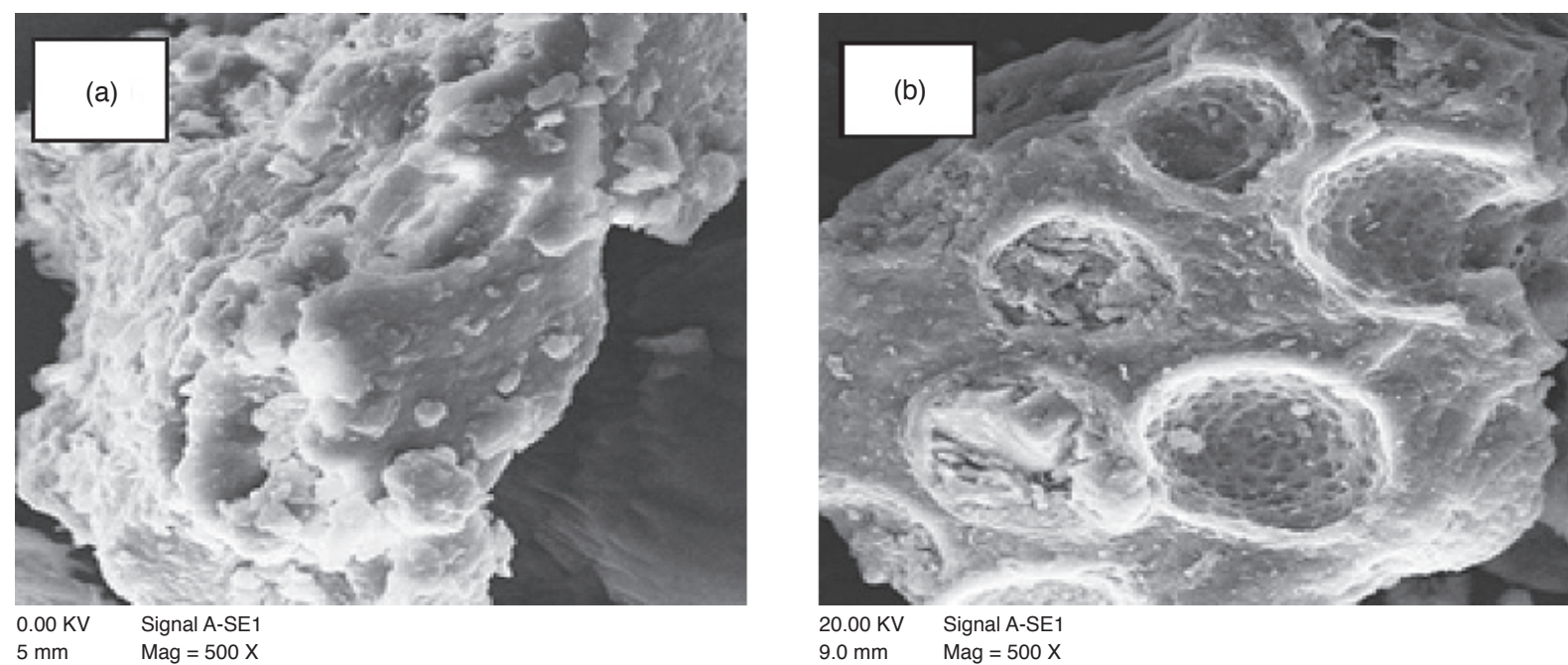

Figure 5. Scanning electron micrograph of bio-char taken at 500X magnification (a) raw mesocarp fibre (MF) and (b) bio-char.

\section{Characterisation of Bio-oil}

The properties of bio-oil before and after enhancement are shown in Table 2. It can be observed that the oil treatment with sago significantly improved the quality of the oil. The oxygen and water contents of the improved bio-oil (bio-oil binder) were reduced after the improvement and consequently increased the carbon and calorific value, respectively. In addition, the viscosity, density, and $\mathrm{pH}$ were increased. The $\mathrm{pH}$ of the bio-oil before and after enhancement is 3.14 and 4.76, respectively. Water and oxygen contents were reduced to 29 wt. $\%$ and 60.33 wt. $\%$ from 73 wt. $\%$ and 74.88 wt. $\%$ after the oil improvement, respectively. Moreover, the viscosities and densities of bio-oil improved from $1.9 \mathrm{cP}$ to $49.6 \mathrm{cP}$ and $1037 \mathrm{~kg} \mathrm{~m}^{-3}$ to $1529 \mathrm{~kg}$ $\mathrm{m}^{-3}$ after enhancement. The calorific value of bio-oil upgraded from 17.06 $\mathrm{MJ} \mathrm{kg}^{-1}$ to $21.23 \mathrm{MJ} \mathrm{kg}^{-1}$. The highly viscous nature of sago is responsible for the increase in the bio-oil viscosity and density.

TABLE 2. THE PHYSICO-CHEMICAL PROPERTIES OF BIO-OIL

\begin{tabular}{lcc}
\hline Material & Bio-oil & Improved bio-oil \\
\hline Physical properties & & \\
Water content $(\mathrm{wt} . \%)$ & 73.00 & 29.00 \\
Density $\left(\mathrm{kg} \mathrm{m}^{-3}\right)$ at $25^{\circ} \mathrm{C}$ & 1037 & 1529 \\
Viscosity $(\mathrm{cP})$ at $25^{\circ} \mathrm{C}$ & 1.90 & 49.6 \\
pH & 3.14 & 4.76 \\
Chemical analysis ${ }^{\text {a }}\left(\mathrm{wt}^{\circ} \%\right)$ & & \\
Carbon & 14.87 & 28.11 \\
Hydrogen & 9.58 & 0.67 \\
Nitrogen & 74.88 & 10.84 \\
Oxygen & & 60.33 \\
Calorific value $\left(\mathrm{MJ} \mathrm{kg}^{-1}\right)$ & 0.72 & \\
Higher heating value & 17.06 & 21.23 \\
Lower heating value & 15.00 & 18.90 \\
\hline
\end{tabular}

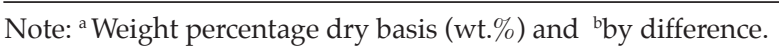

Figure 6 shows the FTIR spectrum of the bio-oil and the improved bio-oil. It was observed that most of the functional groups found in raw MF were also present in the bio-oils. The $\mathrm{O}-\mathrm{H}$ absorption vibration at $3600 \mathrm{~cm}^{-1}$ indicates the presence of alcohol in the bio-oils. The narrow and weak absorption $(\mathrm{C}-\mathrm{H}$ stretching) peak around $2850-2950 \mathrm{~cm}^{-1}$ represents the occurrence of an alkane. The small peak at about $2260 \mathrm{~cm}^{-1}$ indicated the presence of triple bonds functional groups (nitrile). The high signal at 1737 corresponds to $\mathrm{C}=\mathrm{O}$ stretching indicating the occurrences of esters. The multiple medium bands between 1444 and $1599 \mathrm{~cm}^{-1}$ which correspond to $\mathrm{C}=\mathrm{C}$ stretching showed the occurrences of aromatic compounds. Alcohol, carboxylic acids, ester, and ethers were present in the bio-oils at bands around $1000-1300 \mathrm{~cm}^{-1}$ which correspond to C-O stretching vibrations. Similar results were reported by Sulaiman and Abdullah (2011). Though, among the bio-oils, the intensities of the improved bio-oil were low at 3600, 2900, 1700, 1250 and $750 \mathrm{~cm}^{-1}$. This could be attributed to the content of sago starch added in the bio-oil.

\section{Characterisation of Charcoal Briquettes}

The combustible materials for domestic use are described as simply ignitable. However, low porosity, low volatility content, and high ash content would probably diminish the ignitability. The moisture content affects the calorific value of briquettes (Demirbas, 1998). Table 3 shows the physical and chemical properties of bio-char and briquettes. From the proximate analysis, it was observed that the values of volatile matter, ash content and fixed carbon of bio-char and briquettes were almost similar. The volatile matter, ash, and fixed carbon contents were found to be respectively 52.1 wt. $\%, 7.3$ wt. $\%$ and 40.6 wt. $\%$ for bio-char, 
53.15 wt. $\%, 5.75$ wt. $\%$ and 41.1 wt. $\%$ for briquettes obtained using the bio-oil binder and 53.9, 6.8 and $39.3 \mathrm{wt}$ \% for briquettes obtained using sago binder. Heating value is the first parameter that determines the quality of fuels (Demirbas, 1998). The HHV of bio-char, briquettes obtained from bio-oil and sago binders were found to be $27.3 \mathrm{MJ} \mathrm{kg}^{-1}, 29.1 \mathrm{MJ}$ $\mathrm{kg}^{-1}$, and $24.45 \mathrm{MJ} \mathrm{kg}^{-1}$, respectively. The briquette produced with the bio-oil binder had the highest HHV than bio-char and briquette produced with the sago binder. The carbon and hydrogen contents were found to be respectively $60.82 \mathrm{wt} . \%$ and 4.93 wt.\% for bio-char 60.9 wt. $\%, 4.9$ wt. $\%$ for briquette with a bio-oil binder and 59.9 wt. $\%, 4.35$ wt. $\%$ for briquettes produced with sago binder. The nitrogen and oxygen contents for all the fuels were in the range of $0.89-0.97$ wt. $\%$ and 33-35 wt. \%, respectively. This indicates that the application of bio-oil as a binder increase the carbon content of briquettes.
Other parameters of the briquettes are listed in Table 4; they are water resistance, shatter index, density and compressive strength. The shatter index, density and compressing strength represent the mechanical durability of briquette (Kask et al., 2010). From the water resistance test, it was found that the water absorbed by briquettes were $0.25 \mathrm{wt} . \%$ and 0.4 wt.\% for bio-oil and sago binders, respectively. The compressive strength of briquettes is one of a factor that determines the capacity of briquettes to be stored and transported with no damage (Stephen, 2013). The compressive strength was found to be respectively $2.19 \mathrm{~N} \mathrm{~mm}^{-2}$ for briquettes produced with a bio-oil binder and $4.2 \mathrm{~N} \mathrm{~mm}^{-2}$ for briquettes produced with sago binder. The shatter index indicates the weight loss and weight remained (shatter resistance) after the briquettes samples were subjected to dropping. The shatter strength and weight loss were found to be respectively $83.6 \%$ and

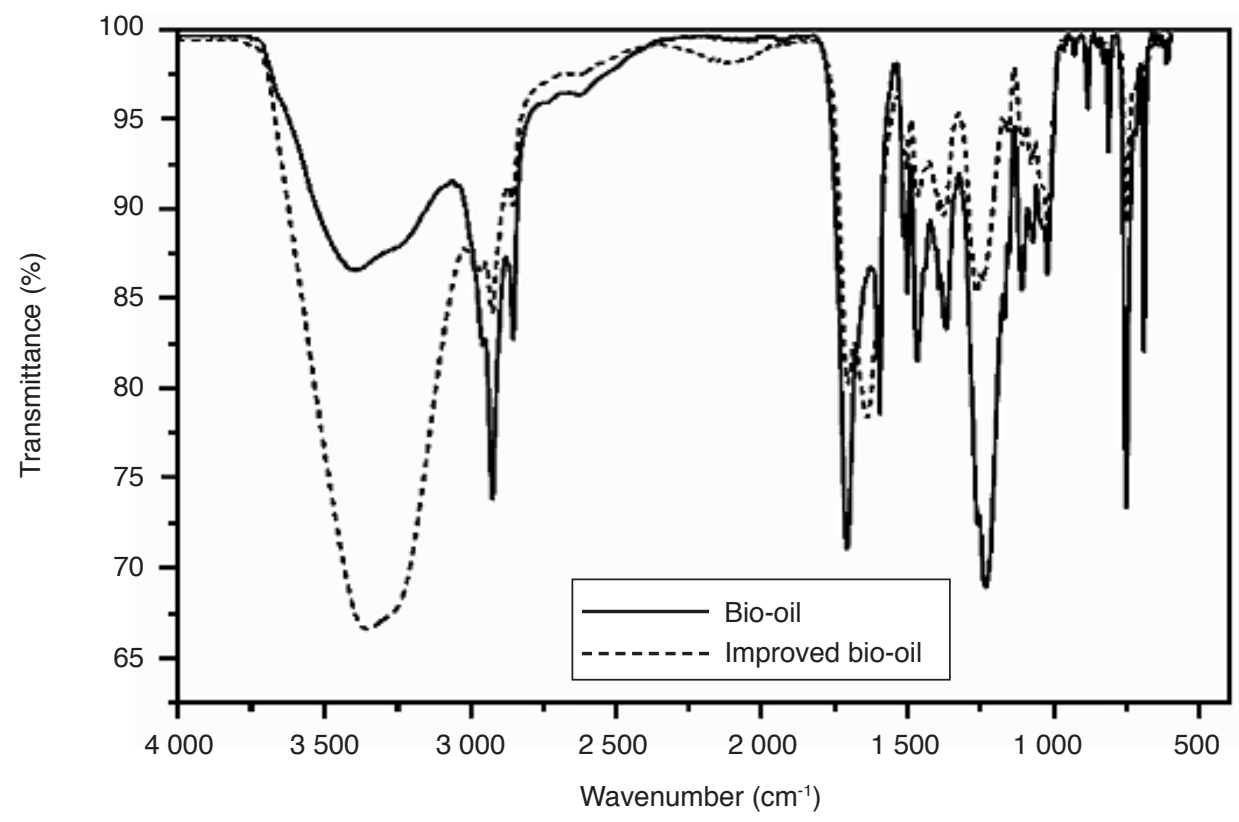

Figure 6. The spectra result of bio-oils.

TABLE 3. THE PHYSICO-CHEMICAL PROPERTIES OF BIO-CHAR AND BRIQUETTES

\begin{tabular}{lccc}
\hline Materials (wt. $\%$ ) & Bio-char & Briquette with oil binder & Briquette with sago binder \\
\hline $\begin{array}{l}\text { Proximate analysis } \\
\text { a }\end{array}$ & & & \\
$\quad$ Moisture content & 3.60 & 2.70 & 1.70 \\
$\quad$ Volatile matter & 52.10 & 53.15 & 53.90 \\
$\quad$ Ash content & 7.30 & 5.75 & 6.80 \\
$\quad$ Fixed carbon & 40.60 & 41.10 & 39.30 \\
Chemical analysis $^{\mathrm{a}}$ & & & \\
$\quad$ Carbon & 60.82 & 60.90 & 59.61 \\
$\quad$ Hydrogen & 4.93 & 4.92 & 4.35 \\
$\quad$ Nitrogen & 0.95 & 0.89 & 0.95 \\
$\quad$ Oxygen & 33.29 & 33.31 & 35.11 \\
Calorific value (MJ kg & & & \\
$\quad$ Higher heating value & 26.30 & 29.12 & 25.41 \\
$\quad$ Lower heating value & 25.21 & 28.52 & 24.50 \\
\hline
\end{tabular}

Note: ${ }^{a}$ Weight percentage dry basis (wt.\%) and by difference. 
TABLE 4. PHYSICAL ANALYSIS OF BRIQUETTES

\begin{tabular}{lcc}
\hline Physical analysis & $\begin{array}{c}\text { Briquette with } \\
\text { oil binder }\end{array}$ & $\begin{array}{c}\text { Briquette with } \\
\text { sago binder }\end{array}$ \\
\hline Water resistance $(\mathrm{wt} . \%)$ & 0.25 & 0.40 \\
Density $\left(\mathrm{g} \mathrm{cm}^{-3}\right)$ & 1.00 & 0.80 \\
Shatter resistance $(\%)$ & 83.60 & 90.3 \\
Compressive strength $\left(\mathrm{N} \mathrm{mm}^{-2}\right)$ & 2.19 & 4.20 \\
\hline
\end{tabular}

$16.4 \%$ for briquettes obtained from the bio-oil binder and $90.3 \%$ and $9.7 \%$ for briquettes derived from sago binder. Higher compressive strength and shatter index indicate greater durability of briquettes. The density of briquettes obtained using bio-oil and sago binders were found to be $1.0 \mathrm{~g} \mathrm{~cm}^{-3}$ and 0.8 $\mathrm{g} \mathrm{cm}^{-3}$, respectively. The density value determines the energy/volume ratio of briquettes (Demirbas, 1998). As density is increased, the energy/volume ratio is also increased. Hence, high-density products are desirable with respect to transportation, storage and handling (Kask et al., 2010). The estimated cost for producing $20 \mathrm{~kg}$ of charcoal briquette is around RM 20 using sago starch. However, the price may be higher with a bio-oil binder. Relatively, the heating value of sub-bituminous Malaysian coal and bakau wood briquettes star fire commercial briquettes were 24.60 and $25.01 \mathrm{MJ} \mathrm{kg}^{-1}$, respectively, lower than charcoal briquette produced in this study.

\section{CONCLUSION}

This work showed that the production of briquettes from the mixture of pyrolysis products is feasible. The bio-oil content was used as a binder to enhance the viscosity. The results have shown that applying bio-oil as binder improved the calorific value of briquettes when compared to briquettes produced with sago starch binder. It can also be concluded that briquettes obtained with bio-oil binder have a higher density and water resistance than briquettes obtained with sago binder. However, sago starch binder demonstrated improved shatter resistance and compressive strength compared to the bio-oil binder. The energy content in bio-oil improved after sago starch was added which reduced the water and oxygen contents of bio-oil. The research could be useful in accelerating the application of biomass, pyrolysis products especially bio-oil through charcoal briquettes manufacturing. And, it may substitute the application of some fossil fuel like coal.

\section{REFERENCES}

ABDULLAH, N and GERHAUSER, H (2008). Biooil derived from empty fruit bunches. Fuel Vol. 87: 2606-2613. DOI:10.1016/j.fuel.2008.02.011.
ABDULLAH, N and SULAIMAN, F (2013). Chapter 3: The oil palm wastes in Malaysia. Biomass NowSustainable Growth and Use (Matovic, M D ed.). DOI: 10.5772/55302.http:/ / www.intechopen.com / books / biomass-now-sustainable-growgth-and-use / the-oil-palm-wastes-in-malaysia.

ABNISA, F; ARAMI-NIYA, A; DAUD, W W and SAHU, J (2013a). Characterization of bio-oil and biochar from pyrolysis of palm oil wastes. BioEnergy Research Vol. 6: 830-840. DOI 10.1007/s12155-0139313-8.

ABNISA, F; ARAMI-NIYA, A; DAUD, W W; SAHU, $\mathrm{J}$ and NOOR, I (2013b). Utilization of oil palm tree residues to produce bio-oil and bio-char via pyrolysis. Energy Conversion and Management Vol. 76: 10731082. DOI:org/10.1016/j.enconman.2013.08.038.

ADISAK PATTIYA; JAMES O TITILOYE and ANTHONY V BRIGDWATER (2006). Fast pyrolysis of agricultural residues from cassava plantation for bio-oil production. Paper presented at the $2^{\text {nd }}$ Joint International Conference on Sustainable Energy and Environment. Bangkok, Thailand. 21-23 November 2006.

AZIZ, S M A; WAHI, R; NGAINI, Z and HAMDAN, $S$ (2013). Bio-oils from microwave pyrolysis of agricultural wastes. Fuel Processing Technology Vol. 106: 744-750. DOI:org/10.1016/j.fuproc.2012.10.011.

BARONI, E D; TANNOUS, K; RUEDA-ORDONEZ, Y J and TINOCO-NAVARRO, L K (2016). The applicability of isoconversional models in estimating the kinetic parameters of biomass pyrolysis. J. Thermal Analysis and Calorimetry Vol. 123: 909-917. DOI 10.1007/s10973-015-4707-9.

FASIHUDDIN, B A; PETER, A W; JEAN-LOUIS, D; SYLVIE, D and BULEON, A (1999). Physico-chemical characterisation of sago starch. Carbohydrate Polymers Vol. 38: 361-370.

GARCIA-JARAMILLO, M; COX, L; KNICKER, H E; CORNEJO, J; SPOKAS, K A and HERMOSIN, M C (2015). Characterization and selection of biochar for an efficient retention of tricyclazole in a flooded alluvial paddy soil. J. Hazard Mate Vol. 286: 581-588. DOI:org/10.1016/j. jhazmat.2014.10.052.

IDRIS, S S; RAHMAN, N A and ISMAIL, K (2012). Combustion characteristics of Malaysian oil palm biomass, sub-bituminous coal and their respective blends via thermogravimetric analysis (TGA). Bioresource Technology Vol. 123: 581-591. DOI:org/10.1016/j.biortech.2012.07.065. 
JAHIRUL, M; RASUL, M; CHOWDHURY, A and ASHWATH, N (2012). Biofuels production through biomass pyrolysis -A technological review. Energie Vol. 5: 4952-5001. DOI:10.3390/en5124952.

KALIYAN, N and VANCE MOREY, R (2009). Factors affecting strength and durability of densified biomass products. Biomass and Bioenergy Vol. 33: 337359. DOI:10.1016/j.biombioe.2008.08.005.

KASK, Ü; ŠOOŠ, L; KRIŽAN, P; LAURMAA, V; ARUNIIT, A; KULU, P and KERS, J (2010). Determination of physical, mechanical and burning characteristics of polymeric waste material briquettes. Estonian J. Engineering Vol. 16: 307. DOI: 10.3176/eng.2010.4.06.

KONG, S-H; LOH, S-K; BACHMANN, R T; RAHIM, $S$ A and SALIMON, J (2014). Biochar from oil palm biomass: A review of its potential and challenges. Renewable and Sustainable Energy Reviews Vol. 39: 729739. DOI:org/10.1016/j.rser.2014.07.107.

LAM, P S; LAM, P Y; SOKHANSANJ, S; LIM, C J; BI, $X$ T; STEPHEN, J D; PRIBOWO, A and MABEE, W E (2015). Steam explosion of oil palm residues for the production of durable pellets. Applied Energy Vol. 141: 160-166. DOI: org/10.1016/j.apenergy.2014.12.029.

MAHMOOD, W; ARIFFIN, M; HARUN, Z; ISHAK, N; GHANI, J and RAHMAN, M (2015). Characterisation and potential use of biochar from gasified oil palm wastes. Special Tissue on $4^{\text {th }}$ International Technical Conference 2014. School of Engineering, Taylor's University. p. 45-54.

MORAL, U and ŞENSÖZ, S (2015). Pyrolysis of hornbeam shell (Carpinus betulus L.) in a fixed bed reactor: Characterization of bio-oil and biochar. Fuel Vol. 150: 672-678. DOI: org/10.1016/j. fuel.2015.02.095.

MOREY VANCE (2009). Biomass densification. Paper presented at the Workshop on Biomass Conversion to Heat and Electricity. Heartland Community College, University of Minnesota. 11 March 2009.
SOHI SARAN; LOPEZ-CAPEL ELISA, E; KRULL EVELYN and BOL ROLAND (2009). Biochar, climate change and soil. A review to guide future research. Commonwealth Scientific and Industrial Reseach Organization Land and Water Science Report 05/09. CSIRO, Australia.

STEPHEN, J M; FRIMPONG-MENSAH, $\mathrm{K}$ and NICHOLAS, A D (2013). Effect of species, particle size and compacting pressure on relaxed density and compressive strength of fuel briquettes. I. J. Energy and Environmental Engineering.

SULAIMAN, F and ABDULLAH, N (2011). Optimum conditions for maximising pyrolysis liquids of oil palm empty fruit bunches. Energy Vol. 36: 2352-2359. DOI:10.1016/j.energy.2010.12.067.

SULAIMAN, F; ABDULLAH, N; GERHAUSER, H and SHARIFF, A (2011). An outlook of Malaysian energy, oil palm industry and its utilization of wastes as useful resources. Biomass and Bioenergy Vol. 35: 3775-3786. DOI:10.1016/j.biombioe.2011.06.018.

SUPARIN, C; SUWAIT, S and PRATTANA, K (2007). Development of fuel briquettes from biomass-lignite blends. J. Sci Vol. 35(1): 43-50.

TEMBE, E T; OTACHE, P O and EKHUEMELO, D O (2014). Density, shatter index, and combustion properties of briquettes produced from groundnut shells, rice husks and saw dust of Daniellia oliveri. J. Applied Biosciences Vol. 82: 72-72.

UEMURA, Y; OMAR, W N; TSUTSUI, T and YUSUP, S B (2011). Torrefaction of oil palm wastes. Fuel Vol. 90: 2585-2591. DOI:10.1016/j.fuel.2011.03.021.

XIU, S and SHAHBAZI, A (2012). Bio-oil production and upgrading research. A review. Renewable and Sustainable Energy Reviews Vol. 16: 4406-4414. DOI:org/10.1016/j.rser.2012.04.028.

YANG, H; YAN, R; CHEN, H; LEE, D H; LIANG, D T and ZHENG, C (2006). Mechanism of palm oil waste pyrolysis in a packed bed. Energy and Fuel Vol. 20: 1321-1328. 